\title{
Child First, Offender Second - A progressive model for education in custody
}

International Journal of Educational Development, Elsevier (CiteScore: 2.8; Impact factor: 1.36)

Accepted 1 July 2020

Stephen Case

Professor of Criminology, Social and Policy Studies, Loughborough University, UK

Neal Hazel

Professor of Criminology and Criminal Justice, School of Health and Society, Salford University, UK

\author{
Keywords \\ Child first \\ Education \\ Engagement \\ Custody \\ Positive \\ Prosocial identity
}

\begin{abstract}
Disengagement and poor educational attainment in education are firmly established risk factors for juvenile crime, leading policymakers to identify educational provision in and after custody as a key pathway for effective reentry (resettlement). However, although there is emerging evidence that children's educational progress can reduce recidivism, persistent issues have dogged the delivery of education in custody across the Western world. We identify these issues as rooted in fundamental weaknesses of the risk paradigm that defines the relationship between custodial education and juvenile justice outcomes, in particular reflecting the absence of a cogent theory of change. We propose an alternative 'Child First' conceptual framework for custodial education that draws on the 'Positive Youth Justice' approach in contemporary youth justice and adopts the development of children's pro-social identity as its theory of change and key purpose. We explore for the first-time what overarching principles such an approach might entail and test the appropriateness of its theory of change by using it to reinterpret existing good practice messages for custodial education.

Therefore, we propose a thoroughgoing evaluation of custodial education practice through such a 'Child First' lens.
\end{abstract}

\section{Introduction}

A range of international juvenile justice jurisdictions continue to highlight the role of education in custody as central to reducing recidivism and promoting positive outcomes for children who offend. However, many jurisdictions also identify poor educational provision in custodial settings, poor integration with other support, and its demonstrable links to consistently negative youth justice outcomes (e.g. recidivism) for children within and beyond custody (O’Neill, 2018; Reed 2018). This paradoxical situation necessitates further examination, both in terms of why it persists (given accepted understandings of the importance of education) and what can be done to address it. In this article, we identify for the first time that persistent issues dogging custodial education internationally are rooted in fundamental weaknesses in the nature of the risk-focused evidence-base that informs and defines its role and relationship with youth justice outcomes. This, in turn, leads us to call for and propose an alternative conceptual framework for custodial education, including a theory of change with which to understand the key role of education in achieving the juvenile justice (known as 'youth justice' in the United Kingdom) aim of reducing recidivism. Within this paper, we examine these two paradigms primarily in relation to the Youth Justice System (YJS) of England and Wales, but the logic of the argument and the 
conceptual framework for educational engagement in custody that is developed from it has wider international relevance.

\section{Educational deficits as a risk factor for youth crime}

Juvenile justice research and policy in the Western world has been dominated by a neo-liberal and neocorrectionalist risk paradigm that seeks to manage the behaviour of children who offend by identifying and targeting 'risk factors' for future offending, rather than prioritising children's engagement in youth justice processes and the pursuit of positive behaviours and outcomes (Stephenson and Allen 2013). The risk paradigm fosters individualised and responsibilizing explanations of offending by framing risk factors as personal 'deficits' (flaws, weaknesses) in psychosocial domains of children's lives (psychological, family, education, peer group, neighbourhood) that children somehow fail or refuse to resist or negotiate (Hampson 2018; Bateman 2011; Case and Haines 2009). In the YJS of England and Wales particularly, a neo-correctionalist punitiveness mobilised by risk-based crime prevention priorities has come to dominate policy and practice, mirroring the new penology in adult criminal justice (Feeley and Simon 1992). It seeks to correct the perceived deficits of children who offend and to punish non-compliance and non-engagement with ameliorative, controlling interventions (see Smith and Gray 2019; Dunkel 2014; Hazel 2008). The risk-led youth justice of England and Wales has, therefore, deprioritised historically important educational and rehabilitative goals for children within and beyond custody (Hopkins-Burke 2016).

Unfortunately, however, the most significant juvenile justice evidence-base implicating the importance of education for children who offend (e.g. resistance to, and desistance from, youth crime) and is located within the reductionist risk paradigm (Stephenson 2017), which forecloses consideration of factors that may promote positive outcomes (e.g. engagement with their own education) due to its overriding deficitfocus on the prevention of 'risk factors' that influence negative outcomes (e.g. reoffending). Primarily, the risk-led association between education and offending outcomes relates to disengagement or absence from education and subsequent conviction/disposal (Blyth, Hayward and Stephenson 2004). A second related set of risks have been established between the attainment of basic educational skills and conviction/disposal (cf. Manguin and Loeber 1996; Farrington et al 2006). Therefore, there is a wellestablished body of risk paradigm research establishing poor educational experience as a 'risk factor' for future re/offending and, conversely, identifying positive education as a protective factor against damaging exposure to risks (Stephenson and Jamieson 2006; Brazier et al 2010), yet no examination of the ‘positive' or ‘enabling' factors for successful juvenile justice outcomes (cf. Case et al 2005).

The main way that this risk association (educational deficiencies-negative outcomes) has been established is through assessing the extent and nature of children's educational needs in juvenile justice systems internationally as typically greater and more complex than for children the general population (see Anderson et al 2016). Perceiving these differences through a risk paradigm lens enables researchers to reconceptualise educational needs as risk factors (i.e. 'criminogenic needs'). This body of research indicates that fewer than half of the children involved with the YJS in England and Wales had had access to full time education, with many not receiving any education for several years (Stephenson and Jamieson, 2006). More recent surveys have presented similar findings (e.g. Stephenson et al, 2014) or worse, with one study showing that $90 \%$ of children in England and Wales receiving a court order were recorded as persistently absent or excluded from school, both of which are established internationally as risk factors for reoffending (MoJ/DfE 2016; Shader 2003; see also Hazel 2016). Assessments of children sentenced to custody identify particularly acute educational (criminogenic) needs. It is estimated that 60 per cent of children in the 'secure estate ${ }^{1}$ ' in England and Wales have learning

\footnotetext{
${ }^{1}$ In the YJS of England and Wales, children given custodial sentences enter the 'secure estate', which consists of three specific types of institution: Young Offender Institutions (YOIs -for children aged 15 and over; mainly those aged 18-21),
} 
difficulties, and 88 per cent have been excluded from school at some point, compared to 3-5\% in the general population (Taylor, 2016; Ravenscroft and Tinkler 2016). Half of children in custody in England and Wales have either identified learning disabilities (20\% - Hughes et al 2012) or borderline learning disabilities (30\% - Hughes 2015). Therefore, assessments in England and Wales (MoJ/DfE 2016; ECOTEC 2001) and the USA (Houchins et al 2008) note that children in custody perform significantly worse (educationally) than their peers due to a toxic mix of educational deficits/risk factors (e.g. disengagement from educational processes), learning difficulties (often reframed as risk factors or 'criminogenic needs'), offending behaviour and experience of juvenile justice systems - all of which constitute barriers to educational engagement and success.

\section{Educational engagement as a rehabilitative tool}

Researchers have emphasised the need to address children's barriers to education within youth/juvenile justice intervention in order to reduce recidivism (Ball and Connolly 2000; Watt et al 2004). Indeed, there is evidence that children who do make progress in education in custody are more likely to return to school on release, and subsequently less likely to be rearrested (Blomberg et al 2011 [USA]; Hazel et al 2002 [England and Wales]). Policymakers across jurisdictions have widely accepted this evidence, viewing education as "a central facet" of work done with children during and after custody to reduce the risk of reoffending, fully incorporating that role into any sentence planning (Stephenson and Jameson 2006: 86; Hazel 2008). In England and Wales, the risk paradigm evidence and consequential role for education in addressing those risk factors directly framed both the Youth Justice Board's specifications for learning and skills (2002) (from the youth justice perspective) and the Department for Education and Skills' specifications for 'learning and skills provision for young offenders' (2004) (from the educational perspective). In addition, 'Education, training and employment' is one of seven key 'pathways' that practitioners should be considered to ensure successful transition of children from custody to the community (Youth Justice Board 2014), with recent policy initiatives such as Secure Colleges and Secure Schools repeatedly aiming to ensure that "education is truly placed at the heart of youth custody" in order to reduce recidivism (Charlie Taylor, 2016: 40).

However, despite the empirical and political importance placed on education for reduced recidivism, there are ongoing international concerns about the poor level of provision both in and after custody both in England and Wales (Little, 2018) and overseas (c.f. Leone and Wruble 2015 [USA]; MacDonald 2018 [Australia]). For example, although schools' inspectors in England and Wales generally rate teaching and the range of courses available in all types of custodial establishment as good quality in itself (Ravenscroft and Tinkler 2016), this masks problems with children's educational reintegration both in and after custody. Almost one in five children in custody in England and Wales reports not receiving any education (Taflan and Jalil 2020) and those in YOIs average 15 hours per week (against a government target of 30 hours weekly - Taylor 2016), with a similar situation existing in the USA (c.f. Reed 2018). Furthermore, only about half of children in England and Wales are typically found to be involved in education or training at some point during their statutory post-custody supervision period (e.g. Hazel et al 2002; Hazel et al 2013; Wright et al 2013). Even in funded re-entry projects (called resettlement in the U.K.), the proportion only rises to about three-quarters of children engaged in postrelease education or training (Hazel et al 2010; Hazel et al 2013; Wright et al 2013). Although it could be argued that these children's personal histories of disengagement, wider care, behavioural emotional and social difficulties (BESD) and speech language and communication difficulties (Anderson et al 2016; Hopkins et al 2016) would always make classroom learning particularly challenging (MoJ/DfE 2016), custody and reentry intervention evaluations have long established that the failure of children to reintegrate into education during or after release is often due to 'organisational or system failure rather

Secure Training Centres (STCs - education-focused secure accommodation for children aged 12-17) and Secure Children's Homes (SCHs - residential care, education and healthcare provision for children aged 10-17). 
than the fault of the young people concerned' (Hagell et al, 2000: 63). We would contend that this 'organisational or system failure' is rooted in the inherent weaknesses and biases of the deficit-focused 'risk paradigm' that defines the relationship between custodial education and juvenile justice outcomes. Indeed, in order to underpin our reconceptualization of the education-custody nexus, we are able to identify key themes to the policy and practice issues raised in research and inspections that reflect closely the weaknesses identified in existing critiques of the risk paradigm in juvenile justice systems more widely:

\section{Provision is not future-focused and strengths based}

Educational provision tends to concentrate on delivering services that manage children's immediate custodial needs and address their previously assessed criminogenic weaknesses rather than look to their future needs and wellbeing (HMI Prisons/HMI Probation 2019a). These services tend to focus on behaviour management, keeping their time occupied and sometimes completion of set courses rather than what is needed to prepare the child for their future. Provision in custody is rarely related to purposeful activity planned or experienced on release, which does not help the child consider their future possibilities (HMI Prisons/HMI Probation 2019b). Indeed, studies and inspections have typically found that only between a third and two thirds of children have post-release education arranged by the time they leave custody (HMI Prisons/HMI Probation 2019a; Hazel 2016). Custodial education's lack of focus on future needs reflects the risk paradigm's overarching focus on addressing negative factors that are assessed to have led to offending in the past or are that currently present a risk. This has been criticised as encouraging retrospective, deficit-led and stigmatising perceptions of children who offend as in need of 'fixing' by adult professionals (Bateman 2011; Haines and Case 2015). Privileging such negative foci distracts professional and systemic attention from constructing children (who offend) as agentic possessors of strengths, capacities, potentialities and rights (e.g. rights to an equitable voice in decisions that affect them) that can be harnessed in the planning and pursuit of positive outcomes (see Butts 2014), which include engagement with education during their time in the YJS. Most importantly, risk-based youth justice can disengage children because it ignores the very fact that they are children with developmental capabilities, needs and power over their lives relative to their 'child' status. To this end, it is important to stress that these identified educational (ad other) 'needs' are not risk factors; they are not the fault, responsibility or deliberate choice of the child, nor should it be (primarily) the child's responsibility to ameliorate them (Haines and Case 2015).

\section{Provision is generic, unengaging and irrelevant to the child}

The key to education progression is engaging the child and keeping them engaged enough to become immersed in learning routines; a challenge which educational provision prior to and during system contact for children who offend is recognised to fail both in terms of children's participation rates and personal commitment (Stephenson et al 2014). A recent review found that children were not engaging with education in the secure estate because they did not find it useful or relevant (Wood et al, 2017). This lack of relevance is mirrored in regular surveys with children in custody, the most recent of which reported only half of children recalling that they had learned anything that would help them when released; a figure that fell to about a quarter of children in one YOI (Taflan and Jalil 2020). In part, this lack of relevance may be attributed to a failure to collaborate and engage with children in planning; only a minority of children are aware of their education training plans (Stephenson 2017); or had a role in deciding targets within them (Cripps and Summerfield 2012). Unsurprisingly then, inspections and studies have noted that education in custody has tended to fit children into generic courses rather than treating them as individuals with their own needs and aspirations for the future (HMI Prisons/HMI Probation 2019b [England and Wales]; Unruh et al 2018). For example, internationally, education is frequently delivered in a traditional classroom model rather than blended or embedded in the child's own lives or concerns (Hawley et al 2013). In particular, there has typically been a limited range of, and a lack of places on, vocational courses in institutions (Hurry et al 2012). Conversely, when such 
courses are available, they may not be matched in community provision once the child is released (Stephenson and Jameson 2006). Considerations of educational engagement, therefore, have often been little more than an addendum to recent juvenile justice policy and practice. This situation mirrors the research and evidence from the wider risk paradigm's de-emphasis of the role of children's perspectives and 'lived experiences' of youth justice in favour of focusing on practitioner skills development in order to form engaging relationships with children (Mason and Prior 2008). Consequently, the concept of engagement in youth justice has been largely defined and understood from the perspective of adult practitioners (e.g. privileging professional skills development - Hopkins, Clegg and Stackhouse 2016), rather than prioritising the need to enhance children's motivation and commitment to become involved in youth justice activities. This completely misses the point that if it is to be effective, engagement (educational and otherwise) needs to be understood and practised from a child's perspective as valid actors rather than passive recipients (e.g. Archer et al 2007). The latter risks disengaging them from education and other constructive youth justice interventions (Creaney and Smith 2014; Drake et al 2014), or even negatively perceiving education as a punishment in itself (Brazier et al 2010).

\section{Provision is isolationist and unintegrated}

Partnerships between education providers and other youth justice agencies has tended to be disjointed, both in England and Wales and elsewhere (Hazel et al 2002; Reed 2018). The demarcation of roles within institution where teachers plan and deliver education in the classroom, with other institutional staff confining their focus to managing offending behaviour HMI Prisons/HMI Probation 2019a) has led to lack of communication and lack of shared understanding between the roles (Andow 2019; Stephenson 2017). Similarly, the sharing of information on education and training that occurred in custody with outside agencies in order to ensure continuity has been a long-standing issue recognised internationally (e.g. ECOTEC 2001, Stephenson et al 2014 [England and Wales]; O’Neill et al 2017 [Australia]; Reed 2018 [USA]). This is both the case in relation to youth justice agencies receiving information from the school where the child last attended (Stephenson and Jamieson 2006) and passing on progress to education providers after release (Hazel 2016). It is our view that such demarcation and its negative effects is unsurprising given a lack of clarity that the risk-based model of offending tends to present factors that assess and predict recidivism as unconnected and discrete considerations (e.g. using separate dimensions on risk assessment tools). Recent research has stressed the need for a shared common understanding, purpose and sense of responsibility between those involved in teaching children in and after custody and those responsible for their youth justice residential care (Mathur and Griller Clark 2014; White et al 2019). However, a lack of focus and understanding about how education might work to reduce offending (Brazier et al 2010; Knight 2014) has acted as a barrier to effective educational provision in custody. This situation has precipitated a lack/paucity of partnership working (Stephenson and Jamieson 2006), critical reflection and inter-agency cooperation (Hazel and Hampson, 2015; Hazel et al., 2015), resulting in children receiving separate and unintegrated education and sentence plans (HMI Probation 2015) and reductionist, deficit-led provision that (relatively) neglects considerations of pursuing positive outcomes for these children, including educational engagement and successful re-entry (Hazel and Hampson 2015).

Again, this reflects a recognised weakness in the risk paradigm for juvenile justice, that no overall theory of change has been elaborated that might provide an understanding of how the elements of activity, including education, might cohere towards preventing offending (Hazel et al. 2017). Notwithstanding, the absence of an explicit 'theory of change' within the risk paradigm is a limitation that its proponents have attempted to construct as a benefit:

'risk factors and interventions are based on empirical research rather than theories. The paradigm avoids difficult theoretical questions about which risk factors have causal effects.' (Farrington 2000: 
However, without a cogent theory of change, it is difficult to see how critical, reflective practice can be employed in order to rationalise, evaluate, improve and even replace contemporary (risk-based) youth justice interventions to benefit children. Research examining custody and re-entry specifically has found that decontextualized nature of the risk-focused practice messages has hindered. Any possible theory of change that could be discerned from the risk paradigm evidence-base would inevitably reflect the reductionist nature of the model, constructing children who offend as laden with deficits (risk factors) that they cannot negotiate without the support of adult practitioners and enforced intervention.

Identifying the critical themes that underly the provision of custodial education for children enables us to represent them as weaknesses reflective of those in the wider risk paradigm and thus to offer a clear explanation of poor levels of children's educational reintegration both in and after custody that moves beyond individualised factors such as existing unmet needs and cognitive barriers to education. Arguably then, the persistence and prevalence of these issue suggests that there is a pervasive or fundamental problem with the way that custodial education is currently framed and understood; that its relationship with juvenile justice outcomes, and thus its role, needs to be rethought if its potential in relation to positive child outcomes and reduced reoffending is to be realised. Indeed, a recent report of youth custody provision in the YJS of England and Wales concluded that the whole of the current education and training should be 'reviewed and re-provided' (Wood et al, 2017: 8). In order to facilitate that, we contend that custodial education requires a paradigm shift and a new conceptual framework to understand its role in youth justice, informed by a cogent theory of change. In particular, this would need to counter the persistent issues identified, by positioning custodial education in a way that allows a strengths-based approach that is relevant to the child and integrated with the rest of their support towards positive outcomes and reduced recidivism.

\section{Child First: A new conceptual framework for education in custody}

Given that we have located the root of key issues for custodial education in the way that it is positioned in relation to offending and recidivism outcomes specifically through the criminogenic risk paradigm, we intend to construct an alternative conceptual framework by looking towards approaches in youth and juvenile justice theory that set themselves in opposition to that paradigm. In particular, we propose that a suitable alternative conceptual framework for custodial education, 'Child First', which is constructed by drawing on and applying a combination of two such contemporary models in youth justice - 'Positive Youth Justice' and 'Pro-social identity development'.

\section{Positive Youth Justice: Positioning the 'Child First' in the custodial education-youth justice nexus}

The most coherent challenge to the risk paradigm in youth justice has come from the 'Positive Youth Justice' model (Haines and Case 2015; see also Butts 2014) - an engaging and positive child-friendly approach that radically re-orientates traditional offence/offender-focused and deficit-facing youth justice by emphasising that all provision should prioritise the central principle of 'Children First, Offenders Second'. Positive Youth Justice conceives of offending as only one element of the child's broader social status (see Drakeford 2010), rather than as their defining master status. Through this model, all youth justice practice should be child-friendly, child-appropriate and focused on the whole child, examining the full complexity of their lives, experiences, perspectives, needs, wishes and multifaceted, context-specific interactions. Its adoption in relation to how we understand the education-youth justice nexus in custody reasserts the position of the whole child, rather than an offending risk factor, as the primary focus of concern and intervention. 
As a model of practice with mutually-reinforcing principles, Positive Youth Justice ${ }^{2}$ (Haines and Case 2015; see also Case and Haines 2018) is explicitly positive because it is explicitly opposed to the 'negative', punitive features of risk-based youth justice, such as the (possibly inadvertent) labelling and stigmatisation of children, excessive intervention, 'net-widening', doing justice 'to' not with children and over-emphasising the prevention of negative outcomes (e.g. exposure to risk factors, reoffending). In direct contrast, Positive Youth Justice is based on a series of the inter-related and reciprocal positive practice principles. Positive Youth Justice practice should be child-friendly and child-appropriate, ensuring that work with children at all stages of the YJS is developmentally appropriate and acknowledges their inherent 'child' status and capacity, rather than 'adulterizing' children (treating them like they were adults). Professionals working within juvenile justice systems should prioritise the promotion of positive behaviours/outcomes: focusing prospectively on facilitating positive behaviours (e.g. engagement in prosocial activities) and positive outcomes (e.g. educational attainment, employment), rather than primarily focusing retrospectively on the prevention of negative behaviours (e.g. offending) and outcomes (e.g. exposure to risk).

Child First education that reflects the principles of Positive Youth Justice should prioritise the facilitation of children's meaningful engagement (belief in, commitment to) across youth justice processes and decision-making that affects them, rather than doing justice 'to' them in 'adult-centric' and non-inclusive ways. Crucially, youth justice practice should be perceived as legitimate (Tyler 2011, 2007), enabling children in the YJS to feel that their treatment by official agencies is 'legitimate' in the sense of fair, moral and just (rather than unfair, unjust, punitive), which can increase the likelihood of their engagement and of intervention success, as well as children building positive relationships with the police and youth justice agencies. Finally, juvenile justice systems must focus more on responsibilizing' adult professionals, holding them primarily responsible for enabling children who offend to achieve their full potential and to gain access to support services, guidance and opportunities, rather than holding the relatively powerless and immature child primarily responsible (after Haines and Case 2015).

Accordingly, a Child First conceptual framework of custodial education that draws on the Positive Youth Justice model would prioritise the overarching principles of:

- Children as part of the solution: Custodial education should require that youth justice responses position children as part of the solution, not part of the problem - with practitioners and policy makers working in partnership with children to hold their interests, needs, rights and views as paramount throughout the youth justice process. Education, therefore, needs to be considered in its widest sense. It should not be considered a classroom bound academic exercise, but one that both looks for learning more generally but is also made aware of the negative learning that the custodial environment can bring (Little 2018; Brazier et al 2010);

- Positive foci: Education in custody should divert practitioners from deficit-focused youth justice and towards a positive, child-appropriate approach in which children are rewarded for their achievements and encouraged to maximise their strengths. Education is not a question of eliminating a risk but of providing future-focused structural support that can helps a child achieve their best present and future selves;

\footnotetext{
${ }^{2}$ The USA version of Positive Youth Justice (Butts 2014) advocates for youth justice practice that builds on children’s two key assets: learning/doing and attaching/belonging, in order to promote prosocial behaviour and resistance to risk (see also Case and Haines 2018).
} 
- Child-focused adults: It is crucial that adult practitioners view themselves as working for the children with whom they engage, rather than as representatives of other interest groups (for example, the YJS, community, victims). As such, the starting point for planning and delivery is the individual aims, motivations and lived context of the child (Brazier et al 2010);

- Children's rights: The priority for adult youth justice practitioners delivering education in custodial settings in the YJS must be to engage closely and regularly with children, facilitating the expression of the child's views on issues that affect them (cf. Article 12 of the United Nations Convention on the Rights of the Child). It should enable equitable participation in decisionmaking regarding their futures (Clare Taylor 2016), and promoting access to the child's universal entitlements as set out in progressive policy statements and international conventions;

- Engagement-based relationship-building: Custodial education should emphasise positive and trusting relationships through which constructive interactions can be facilitated, rather than the formal learning per se. Positive relationships have been recognised as key in managing behaviour (Elwick et al 2013), and role modelling (Knight 2014), but are also vital for fostering engagement (Clare Taylor 2016). Engagement is conceptualised here not just as participation but as feeling a commitment based on the child's perceived relevance of the education to the way they see themselves and their future identity (Bateman and Hazel 2013).

\section{Pro-social identity development: A 'Child First' theory of change for custodial education}

We have argued that the themes of unintegrated and disengaging provision are persistent issues for custodial education that are rooted in a fundamental weakness of the risk paradigm; the lack of a theory of change for how it relates to reduced recidivism. We propose a new theory of change to understand the relationship between education and youth justice outcomes and to animate the principles of Positive Youth Justice in practice, based on contemporary research understandings about the journey of the child through custody and reentry. The 'Beyond Youth Custody' research project (BYC) concluded that successful reentry of children after custody can be understood as a personal journey involving a shift in identity (Hazel et al 2017). Reflecting the process of 'secondary desistance' established in the adult criminological literature (cf. Maruna and Farrall 2004; McNeill and Weaver 2010), the research identified successful reentry as encouraging the child's pro-social identity development. Consequently, reentry support should be reconceptualized, not as addressing decontextualized risk factors, but as facilitating the child's pro-social identity development (Hazel and Bateman 2020). As such, the BYC research provides the 'Child First' model of Positive Youth Justice with a vital theory of change regarding how education can influence the behaviour and development of children in custody, simultaneously addressing the restricted evidence-base regarding the nature of the relationship between education, desistence, resistance and positive outcomes for children who offend ${ }^{3}$ (Knight 2014; Hazel and Bateman 2020).

Research in educational psychology has recognised the value of teachers focusing on children's identity development in order to realise educational goals (cf. Gee 2001; Oyserman et al 2006; Kaplan and Flum 2009; Schachter and Rich 2011). For example, it is recognised that educators can help child define their learning abilities positively (Roeser et al 2006), build learning on current identity (e.g. Richardson 1997), and draw on social identity (e.g. ethnicity) to motivate engagement in a topic (Lee and Anderson 2009). However, its potential in relation to educators' role in supporting children towards positive youth justice outcomes has been ignored until now. Conversely, despite evidence in education research that

\footnotetext{
${ }^{3}$ There is some limited evidence that education may reduce recidivism by enhancing the social inclusion of children (Knight 2014), thus increasing their social capital and giving them a stronger sense of agency (Stephenson 2017; Ahlin 2014).
} 
learning can facilitate identity formation (cf. McLean, Breen and Fournier 2010), those outlining the importance of pro-social development for children's desistance have not yet explored how custodial education can actively engage with this process. We contend that this is a conceptual misalignment that, if corrected, will address some of the fundamental problems rooted in the existing risk-based framing of the relationship between custodial education and youth justice outcomes. It would allow a common purpose and language that is broader than academic or even vocational attainment per se and can be shared between staff in education and other agencies.

We propose that custodial education has an important role beyond helping a child formulate identity per se, and beyond aiding educational attainment; it should have a key focus on helping a child develop a pro-social sense of self for secondary desistance purposes. Education should be conceptualised and designed in as part of the wider package of support in and after custody that helps engage them and then facilitates them in developing their best self and their place in the world. It is a social or interactionist view of identity (Jenkins 2008), understanding that a sense of self and place in the world is coconstructed through relations with sociocultural contexts and others (Cote 1996; Roeser et al 2006; Penuel and Wertsch 1995). We argue that education is thus an important vehicle for presenting children with the fresh 'AIR' of activities, interactions and relationships that are the building blocks for exploring and developing pro-social identity for children in trouble (Hazel et al 2020). Indeed, education is perfectly positioned to contribute to both elements of effective casework found in the BYC research to be essential to facilitating pro-social identity development (Hazel and Bateman 2020). First, it can help guide identity development, using educational activities (from crafts to history role-play) to stimulate self-reflection of current identity, highlight child's strengths and interests to inform development, explore potential future pro-social self, and discuss routes towards it. Second, it can help enable identity development by providing some of the structural support identified as part of the route to their future pro-social self, including appropriate skills development and training.

Conversely, it is not necessary for the focus to be on basic academic skills for education to fulfil that role. Indeed, wider youth justice staff can recognise themselves as playing a part in the child's 'education', not just by championing classroom activities, but by building on their advances in prosocial identity development with complementary activities, interactions and roles. Thus, custodial education with this theory of change at the heart of its conceptual framework presents an integrated and engaging Child First relationship between educational professionals and other custodial staff that recognises the accumulative learning potential of different contexts (Stephenson 2017). Indeed, this integrated theory of change would provide a positive common and future focused language for custodial institutions to engage with community education providers to prepare for reentry support, providing an alternative deficit-focused discourse to one often based on the risk of placement (Hazel et al 2013).

The importance placed on the child's own sense of self and agency is similar to recent calls to increase self-belief in order to participate specifically in education, training and employment during and after custody (Stephenson 2017). Indeed, children in custody themselves have made it clear that they value educational opportunities that can build their confidence, motivation and self-esteem in custody more generally (Little 2018). Again, however, the main difference in the conceptual framework presented here that the benefit of this role for education is just not for education attainment per se or improved motivation per se, but is explicitly for broader identity development and secondary desistance. It provides a theory of change for why education has an important place in improving positive outcomes for these children (e.g. engagement with education, training or employment) and thus can indirectly reduce recidivism. Indeed, using a checklist of characteristics for effective reentry support (the '5Cs', Hazel and Bateman 2020), we can reinterpret many of research messages that already exist for custodial education in relation to how they may actually be helping to facilitate pro-social identity development. For example: 
- Constructive: Making learning in custody meaningful and relevant to children and their future aspirations is recognised as essential to reengage children both in custody and after release (Stephenson 2017; Snow et al 2015; Stephenson and Jamieson 2006; Little 2015; Clare Taylor 2016). 'Relevant' here can be understood as being relatable to the child's identity, their future self or the route to get there. Indeed, education both inside and after custody is in a very good position to move the focus of interventions from past offence to future opportunities for motivating pro-social involvement and identity (Brazier et al 2010; MacDonald 2020). Vocational approaches may be particularly engaging because they tend to link well to both out of school knowledge (David and Florian 2004) and an existing out of custody identity or to a future self;

- Customised: Each child's identity and identity development route is individual, emphasising the need and effectiveness of personalised learning (Steele et al 2016; Prisoners' Education Trust 2013; Clare Taylor 2016), embedded in their own lives (Hawley et al 2013). It underlines the importance of resourcing needs to be considered in relation to a child's individual identity route rather than fitting plans around existing resources (Griller Clark et al 2016; HMI Prisons/HMI Probation 2019b). Focusing on the child's individual interests, strengths and routes to pro-social identity underlines the need for individualised and flexible teaching content and delivery that permeates classroom walls (Brazier et al 2010);

- Co-created: As someone's identity and identity development is personal to them, so the child's perspective in planning and delivery is vital. This underlines the principle established in literature that education planning should be collaborative, ensuring children have a sense of ownership over their plans (Trotter 2015; Griller Clark 2018), and delivery should be participatory (Clare Taylor 2016). Beyond improved educational outcomes (Little 2015; Kohler et al 2016), this helps to encourage and develop the child's agency, locus of control, empowerment and future-focus (Champion and Aguiar 2013);

- Consistent: The fostering and enabling of identity development requires that all agencies provide consistent constructive messages about the child in a unified aspirational culture (Clare Taylor 2016). The need for a continuous development of identity underlines the importance found in ensuring that provision of courses (particularly vocational courses) are matched between custody and community (Stephenson and Jamieson 2006). As a developmental journey, continuity also benefits from starting to plan for and arrange suitable education for each stage as soon as the child enters custody, if not before (Bateman et al 2013; MacDonald et al 2020; Clare Taylor 2016). Having relationships cross the custody-community divide, perhaps by having future teachers visit in custody (Strnadová et al 2017), will help to avoid disruption in identity that can come at transitions (Day et al 2020);

- Coordinated: A shared recognition between agencies of the child's identity aspirations and route will enable each to play their part in its identification, fostering and enabling. This underlines the importance of linking effectively with other parts of the institution (Stephenson and Jamieson 2006), community agencies (Frey 1999) and the family (Clare Taylor 2016). The need for a holistic support package to facilitate this for identity development requires the management of each agency's role in a single plan (Hazel et al 2010; Griller Clark et al 2016; Reed 2018) and swift transition of records between agencies (Bateman et al 2013; Griller Clark et al 2016). 


\section{Conclusion: The urgent challenge to operationalise 'Child First' custodial education}

While research identifying educational risk factors for youth crime has helped to develop a clear evidence base for the importance of education in youth custody, it has also saddled it with an operational framework that reflects many of the risk paradigm's weaknesses. In particular, this article has identified how themes to persistent criticisms of custodial education, as not being future-focused, being generic and irrelevant to the child, and as unintegrated with wider support, all reflect the respective criticisms of the risk paradigm as retrospective and deficit-focused, denying the child agency and lacking a unifying theory of change. We assert that these fundamental problems will remain unless there is a paradigm shift in the way that the relationship between education and youth justice outcomes is framed. Consequently, we call for a new conceptual framework to understand the role of custodial education in youth justice that reframes and realigns it as positive strengths-based, relevant and integrated.

We have proposed an alternative conceptual framework for education in custody by looking towards approaches in youth justice theory that set themselves in opposition to the risk paradigm. First, a 'Child First' conceptual framework draws on the Positive Youth Justice model in repositioning the whole child as the primary focus of concern and intervention in the education-youth justice nexus. Our re-imagined framework for educational engagement in custody would prioritise child-friendly and child-appropriate educational practice and access to learning in the juvenile justice system, calling for legitimate methods of engagement and collaboration as vehicles for the future-focused promotion of positive outcomes for children. Second, the 'Child First' approach is consolidated and mobilised by the development of a new theory of change for education in custody based in our contemporary understanding of successful reentry: the development of child's prosocial identity. Sharing the purpose of facilitating of prosocial identity development with other agencies provides a framework for how education in custody contributes to both positive child outcomes and contributes to reducing recidivism. It has an important role in providing the activities, interactions and roles (fresh 'AIR') for children to foster their identity development. Indeed, as a test of the appropriateness of this theory of change to custodial education, it was possible to reinterpret the importance of many of the existing research messages in terms of how they would help facilitate pro-social identity development.

'Child First' as an integrated model of Positive Youth Justice and prosocial identity development provides a conceptual framework for educational provision and engagement in custody that is perceived as legitimate (i.e. moral, fair, deserved, equitable) by children in the YJS, thus increasing the likelihood of them investing in, and committing to, the approach (cf. Hawes 2014). In this way, children's engagement with education and with the youth justice professionals who deliver it, goes deeper than the fundamentals of voluntarism, trust, respect and fairness (although these remain essential building blocks of the engagement relationship) and moves towards more positive notions of partnership, reciprocity, investment and the legitimate, meaningful participation in decision-making processes Following the principles of 'Child First' to their natural conclusion, this reconfigured model of custodial educational engagement should not measure children's alleged 'success' or 'failure' in the YJS in terms of their re/offending or exposure to 'risk factors' (as individualised and decontextualized deficits), but in terms of their achievement of (and recognition for) positive outcomes driven by prosocial identity development and facilitated by engaging relationships with adult professionals.

We recognise, however, that such a conceptual model requires operationalisation, with both cultural and practical challenge; it requires a thoroughgoing evaluation of practice through a 'Child First' lens. In the same way that education in mainstream education has explored, to some extent, how to design identity-aware curricula (cf. Dreyer 1994), we call on providers consider how to design custodial education capable of exploring and guiding pro-social identity development specifically. Indeed, in England and Wales, while the paradigm shift advocated in this paper is not yet evident in policy or practice frameworks for custodial education, it is beginning to gain traction in the operating model for 
other elements of the youth justice system. The Youth Justice Board and Ministry of Justice have adopted the 'Children First, Offenders Second' principle of Positive Youth Justice with the pro-social identity development theory of change, as the guiding principle for the YJS for England and Wales, including new National Standards relating to custody and reentry (MoJ/YJB 2019). Until custodial education provision is reframed similarly, there will be an increasing disjunction with the rest of the YJS, further exacerbating the problems with lack of shared understanding and partnership working outlined here. Where education is delivered by specialist education providers rather than institution staff, as is the case in England and Wales, it is essential that the commissioning framework for such education services establishes criteria based around 'Child First' and its central components of Positive Youth Justice and pro-social identity development. We recommend that other jurisdictions follow suit in adopting this approach and theory of change, both for youth justice and the important role of custodial education within it, in order to address the fundamental issues outlined in the paper and to better ensure positive outcomes for children and reduced recidivism. 


\section{References}

Ahlin EM (2014) Locus of control redux: Adolescents' choice to refrain from violence. Journal of Interpersonal Violence, 29, 14, 2695-2717

Anderson S, Hawes D and Snow P (2016). 'Language impairments among youth offenders: A systematic review’. Children and Youth Services Review, 65: 195-203

Andow C (2018), 'Roles and Relationships of Care and Education staff inside a Secure Children's Home’ In D Gallard, J Millington and K Evans (eds.) Children and Their Education in Secure Accommodation: Interdisciplinary perspectives of education, health and youth justice, London: Routledge

Archer L, Hollingworth S and Halsall A (2007) 'University's not for Me - I'm a Nike Person': Urban, Working-Class Young People's Negotiations of 'Style', Identity and Educational Engagement. Sociology, 41(2): 219-237.

Baker, K. (2005) Assessment in Youth Justice: Professional Discretion and the Use of Asset. Youth Justice, 5(2), p.106-22

Ball C and Connolly J (2000) Educationally disaffected young offenders: youth court and agency responses to truancy and school exclusion. British Journal of Criminology, 40(4), p594-616

Bateman, T (2011) 'Punishing poverty: the 'scaled approach' and youth justice practice' in Howard Journal of Penal Reform 50(2): 171-183.

Bateman T and Hazel N (2013) Engaging young people in resettlement: Research report London: Beyond Youth Custody/Nacro.

Bateman T, Hazel N and Wright S (2013) Resettlement of young people leaving custody: Lessons from the literature London: Beyond Youth Custody/Nacro

Berridge D, Brodie I, Pitts J, Porteous D and Tarling D (2001) The independent effects of permanent exclusion from school on the offending careers of young people: RDS Occasional Paper No.71 Crown Copyright

Blomberg T, Bales W, Mann K, Piquero A and Berk R (2011) Incarceration, education and transition from delinquency. Journal of Criminal Justice, 39, 4, 355-365

Blyth M, Hayward G and Stephenson M (2004) 'Effective educational interventions with young people who offend' in Burnett R and Roberts C. (eds) What Works In Probation and Youth Justice. Collompton: Willan Publishing 2004

Brazier L, Hurry J and Wilson A (2010) Post-16 education and training provision for young people involved in crime. London: Institute of Education

Bryan K, Freer J and Furlong C (2007). Language and communication difficulties in juvenile offenders. International Journal of Language and Communication Disorders 42: 505-520 
Butts J (2014) Strengthening Youth Justice Practices with Developmental Knowledge and Principles. Baltimore: Annie E Casey Foundation.

Case SP (2018) Youth Justice: A Critical Introduction. London: Routledge.

Case SP and Haines KR (2009) Understanding youth offending: Risk factor research, policy and practice. Cullompton: Willan.

Case SP and Haines KR (2015) Children First, Offenders Second Positive Promotion: Reframing the Prevention Debate. Youth Justice Journal, 15 (3): 226-239.

Case SP, Clutton S and Haines KR (2005) Extending Entitlement: A Welsh policy for children. Wales Journal of Law and Policy, 4 (2), 187-202.

Champion N and Aguiar J (2013) Involve, Improve, Inspire. London: Prisoners Education Trust

Cote JE (2006). Identity studies: How close are we to developing a social science of identity? An appraisal of the field. Identity,6, 3-25.

Cripps H and Summerfield A (2012) 'Resettlement provision for children and young people' and 'The care of Looked After Children'. Findings from two inspectorate thematic reviews. Prison Service Journal, 201, 31-38.

David P and Florian L (2004) Teaching Strategies and approaches for pupils with SEN: a scoping study. Department of Education and Skills research report RR516 London: DfES

Day A-M, Bateman T and Pitts J (2020) Surviving incarceration: the pathways of looked after and nonlooked after children into, through and out of custody. Bedford: University of Bedfordshire

Department for Education and Skills (2004) The Offender's Learning Journey: Learning and skills provision for juvenile offenders in England. London: DfES

Dreyer PH (1994). Designing curricular identity interventions for secondary schools. In S. L. Archer (Ed.) Interventions for adolescent identity development (pp. 121-140). Thousand Oaks, CA: Sage

Dunkel F (2014) Juvenile Justice Systems in Europe - Reform developments between justice, welfare and 'new punitiveness'. Criminological Studies, 2014/1.

ECOTEC (2001) An audit of education and training provision within the youth justice system. London: Youth Justice Board

Elwick A, Davis M, Crehan L and Clay B (2013) Improving outcomes for young offenders: an international perspective. CfBT Education Trust.

Farrington DP, Gallagher B, Morley B, St Ledger RJ and West DJ (1986) Unemployment, school leaving and crime. British Journal of Criminology, 26, 4, 335-356

Farrington, DP (1996) Understanding and preventing youth crime York: Joseph Rowntree Foundation/York Publishing Services 
Farrington DP, Coid JW, Harnett L, Jolliffe D, Soteriou N, Turner R and West DJ (2006) Criminal careers and life success: new findings from the Cambridge Study in Delinquent Development. London: Home Office.

Feeley M and Simon J (1992) The New Penology: Notes on the emerging strategy of corrections and its implications Criminology 30 (4): 449-474.

Frey HE (1999) Employment and Training for Court-Involved Youth: An Overview. Washington: Office of Juvenile Justice and Delinquency Prevention, U.S. Department of Justice.

Gee PJ (2001) Identity as an analytic lens for research in education. Review of Research in Education, 25, 99-125

Griller Clark H (2018) Involvement of the young person in transition planning. In SC O’Neill (ed) Incarcerated youth transitioning back to the community: International perspectives. Singapore: Springer

Griller Clark H, Mathur SR, Brock L, O’Cummings M and Milligan D (2016) Transition toolkit 3.0: Meeting the educational needs of youth exposed to the juvenile justice system. Washington, DC: National Evaluation and Technical Assistance Center for the Education of Children and Youth Who Are Neglected, Delinquent, or At Risk (NDTAC). 3rd ed. 2016.

Hagell A, Hazel N and Shaw C (2000) Evaluation of Medway Secure Training Centre London: Home Office

Haines, K.R. and Case, S.P. (2015) Positive Youth Justice: Children First, Offenders Second. Bristol: Policy Press.

Hampson, K. (2018) Desistance approaches in youth justice - the next passing fad or a sea-change for the positive? Youth Justice, 18(1); 18-33.

Hawley J, Murphy I and Souto-Otero M (2013) Prison education and training in Europe: Current state-of-play and challenges. Report to the European Commission.

Hazel N (2016) The importance of education and training in effective resettlement. Paper to the Prisoners' Education Trust Academic Symposium, South Bank University, London, 25 ${ }^{\text {th }}$ January 2016

Hazel N and Bateman T (2020) Supporting children's resettlement ('reentry') after custody: Beyond the risk paradigm Youth Justice

Hazel N, Drummond C, Welsh M, and Joseph K (2020) Using an identity lens: Constructive working with children in the criminal justice system. London: Nacro

Hazel N, Hagell A, Liddle M, Archer D, Grimshaw R and King J (2002) Assessment of the Detention and Training Order and its impact on the secure estate across England and Wales. London: Youth Justice Board

Hazel N, Hampson K and Kinsey T (2015) Youth resettlement in Southern Wales, and the Resettlement Broker Project Cardiff: Llamau / YJB Cymru 
Hazel N, Liddle M and Gordon F (2010) Evaluation of RESET: a major resettlement programme for young offenders London: Catch 22

Hazel N, Wright S, Liddle M, Renshaw J and Gray P (2013) Evaluation of the North West Resettlement Consortium: Final Report London: Ministry of Justice

HMI Prisons/HMI Probation (2019a) Youth resettlement work: Interim report into work in custody London: HMI Prisons

HMI Prisons/HMI Probation (2019b) Youth resettlement - final report into work in the community Manchester: HMI Probation

HMI Probation (2015) Joint thematic inspection of resettlement services to children by Youth Offending Teams and partner agencies. Manchester: HMI Probation

Home Office (2004) Every Child Matters: Change for Children in the Criminal Justice System www.everychildmatters.gov.uk/aims/outcomes (accessed 13/11/06)

Hopkins-Burke, R. (2016) Young People, Crime and Justice. Abingdon: Routledge.

Hopkins, T., Clegg, J. and Stackhouse, J. (2016), Young offenders' perspectives on their literacy and communication skills. International Journal of Language and Communication Disorders, 51: 95-109.

Houchins DE, Jolivette K, Krezmien MP and Baltodano HM (2008) A multi-state study examining the impact of explicitly reading instruction with incarcerated students. Journal of Correctional Education, $59,65-85$

Hughes N (2015) Neurodisability in the Youth Justice System: recognising and responding to the criminalisation of neurodevelopmental impairment. London: Howard League What is Justice? Working Papers 17/2015

Hughes N, Williams H, Chitsabesan P, Davis R and Mounce L (2012) Nobody Made the Connection: The prevalence of neurodisability in young people who offend. London: The Children's Commissioner

Hurry J and Moriarty V (2004) The national evaluation of the Youth Justice Board's education, training and employment projects London: Youth Justice Board

Hurry J, Rogers L, Simonot M and Wilson A (2012) Inside education: The aspirations and realities of prison education for under 25s in the London area. London: Institute of Education

Jenkins R (2008) Social Identity 3rd edition. Oxon: Routledge

Kendall S, Kinder K, Halsey K, Fletcher-Morgan C, White R and Brown C (2003) An Evaluation of Alternative Education Initiatives DFES Research Brief (RB403) London: DFES

Knight V (2014) Framing education and learning in youth justice in England and Wales: Some outcomes for young offender interventions. British Journal of Community Justice, 12, 1, 49 
Kohler PD, Gothberg JE, Fowler C and Coyle J (2016) Taxonomy for transition programming 2.0: A model for planning, organizing, and evaluating transition education, services, and programs. Western Michigan University

Lee JS and Anderson KT (2009). Negotiating linguistic and cultural identities: Theorizing and constructing opportunities and risks in education. Review of Research in Education, 33, 181-211.

Leone PE and Wruble PC (2015) Education services in juvenile corrections: 40 years of litigation and reform. Education and Treatment of Children, 38, 587-604

Lipsey M and Derzon J (1998) Predictors of serious delinquency in adolescence and early adulthood: A synthesis of longitudinal research. In R Loeber and DP Farrington (eds) Serious and Violent Juvenile Offenders: Risk Factors and Successful Interventions New York: Sage

Little R (2015) Putting education at the heart of custody? The views of children on education in a young offender institution. British Journal of Community Justice 13, 2, 27-46

Little R (2018) Children's views of education in a Young Offenders institution. In D Gallard, J Millington and $\mathrm{K}$ Evans (eds.) Children and Their Education in Secure Accommodation: Interdisciplinary perspectives of education, health and youth justice, London: Routledge

MacDonald F, te Riele K, White J, Corcoran T, Moylan P, Baker A and Manan RA (2020) Educational transition from custody final report. Melbourne: Victoria University/University of Tasmania/Deakin University

Manguin E and Loeber R (1996) 'Academic Performance and Delinquency' in M Tonry (ed) Crime and Justice: A Review of the Research. Chicago: University of Chicago Press

Maruna S and Farrall S (2004) Desistance from Crime: A Theoretical Reformulation. Kolner Zeitschrift fur Soziologie und Sozialpsychologie, 43.

Mathur SR and Griller Clark H (2014) Community engagement for reentry success of youth from juvenile justice: Challenges and opportunities. Education and Treatment of Children, 37(4).

McLean KC, Breen A and Fournier MA (2010) Adolescent identity development: Narrative meaningmaking and memory telling. Journal of Research on Adolescence, 20, 166-187.

McNeill F and Weaver B (2010) Changing Lives? Desistance Research and Offender Management. SCCJR Project Report; No.03/2010

Moffitt, TE (1993) Adolescence-limited and life-course persistent antisocial behaviour: A developmental taxonomy. Psychological Review 100 (4) p.674-701

MoJ/DfE (2016) Understanding the educational background of young offenders: Joint experimental statistical report from the Ministry of Justice and Department for Education. London: MoJ and DfE

MoJ/YJB (2019) Standards for children in the youth justice system 2019. London: Ministry of Justice

Morgan R (2007) Forward. In M Stephenson, Young people and offending: Education, justice and social inclusion. Collompton: Willan 
O’Neill SC (2018) Transitions in the lives of incarcerated youth. In O'Neill SC (ed.) Incarcerated youth transitioning back to the community: International Perspectives. Sydney: Springer

O’Neill SC, Strnadová I, Cumming TM (2017). Systems barriers to community reentry for incarcerated youths: A review. Children and Youth Services Review. 79(C):29-36.

Oyserman D, Bybee D, and Terry K (2006) Possible selves and academic outcomes: When and how possible selves impel action. Journal of Personality and Social Psychology. 91, 1, 188-204.

Pawson R and Tilley N (1997) Realistic evaluation. London: Sage

Penuel W and Wertsch J (1995). Vygotsky and identity formation: A sociocultural approach. Educational Psychologist, 30, 83-92.

Prisoners Education Trust (2013) Response to Transforming Youth Custody consultation. London: Prisoners Education Trust.

Ravenscroft S and Tinkler J (2016) Education in youth custody. Houses of Parliament Postnote, 524, May 2016. London: Parliamentary Office of Science and Technology

Reed DK (2018) Education for U.S. youth in secure care. In D Gallard, J Millington and K Evans (eds.) Children and Their Education in Secure Accommodation: Interdisciplinary perspectives of education, health and youth justice, London: Routledge

Richardson V (ed) (1997). Constructivist teacher education: Building new understandings. New York, NY: Taylor and Francis.

Roeser RW, Peck SC, and Nasir NS (2006) Self and identity processes in school motivation, learning and achievement. In P. A. Alexander and P.H. Winne (Eds.) Handbook of educational psychology. Mahwah, NJ: Erlbaum

Rogers L, Simonot M and Nartey A (2014) Prison Educators: Professionalism Against the Odds. IOE and UCL London.

Schachter EP and Rich Y (2011) Identity education: A conceptual framework for educational researchers and practitioners. Educational Psychologist, 46, 4, 222-238

Shader M (2003) Risk Factors for Delinquency: An Overview. Washington: OJJDP.

Smith R and Gray P (2018) The changing shape of youth justice: Models of practice. Criminology and Criminal Justice, 19 (5): 554-571.

Snow P and Powell M (2012) Youth (In)justice: Oral language competence in early life and risk for engagement in antisocial behaviour in adolescence. Trends and Issues in crime and criminal justice, 435. Canberra: Australian Institute of Criminology

Snow P, Sanger DD, Claire LM, Eadie PA and Dinslage T (2015) Improving Communication Outcomes for Young Offenders: a proposed response to intervention framework. Internal Journal of Communication Disorders, 50, 1, 1-13. 
Sparkes J and Glennerster H (2002) Preventing social exclusion: education’s contribution. In J Hills, J Le Gran and D Piachaund (eds) Understanding Social Exclusion. Oxford: Oxford University Press

Steele JL, Bozick R and Davis LM (2016) Education for incarcerated juveniles: A meta-analysis. Journal of Education for Students Placed at Risk, 21, 65-89.

Stephenson M (2017) Education, Training and Employment. In M Stephenson and R Allen (Eds) Exploring Youth Justice. Norwich: Unitas

Stephenson M and Allen R (2013) Youth justice: Challenges to practice. London: UNITAS.

Stephenson M and Jamieson J (2006) Barriers to engagement in education, training and employment. London: Youth Justice Board.

Stephenson M, Adams M, Tarling R (2014) The art of engagement? Outcomes and impact of the Summer Arts College Programme 2007-12 (second edition). London: Unitas

Steurer S, Smith L and Tracy R (2001) Three State Recidivism Study Lanham MD: Correctional Education Association

Strnadová I, Cumming TM, O’Neill SC (2017) Young people transitioning from juvenile justice to the community: Transition planning and interagency collaboration, Current Issues in Criminal Justice. 29(1):19-38

Taflan P and Jalil R (2020) Children in custody 2018-19. London: HM Inspectorate of Prisons Taylor, Charlie (2016) Review of the youth justice system in England and Wales London: Ministry of Justice

Taylor, Clare (2016) Great Expectations: Towards better learning outcomes for young people and young adults in custody. London: Prisoners’ Education Trust

Tolbert M (2002) State correctional education programs: State Policy Update. Washington, DC: National Institute for Literacy.

Tyler T (2007) Legitimacy and Criminal Justice: International Perspectives. New York: Russell Sage Found Tyler T (2011) Why people cooperate. The role of social motivation. Princeton and Oxford: Princeton University Press.

Unruh DK, Gagnon JC and MaGee C (2018) Community reintegration for young offenders in the United States of America. In In O'Neill SC (ed.) Incarcerated youth transitioning back to the community: International Perspectives. Sydney: Springer

Utting D (1996) Reducing criminality among young people: a sample of relevant programmes in the United Kingdom. Home Office Research Study 161. London: Home Office

Watt B, Howells K and Delfabbro P (2004) Juvenile Recidivism: Criminal Propensity, Social Control and Social Learning Theories. Psychiatry, Psychology and Law, 11(1), p.141-153 
White J, te Riele K, Corcoran T, Baker A, Moylan P and Manan RA (2019) Improving educational connection for young people in custody Final report. Melbourne: Victoria University

Wood A, Bailey S and Butler R (2017) Findings and recommendations of the Youth Custody Improvement Board. London: Ministry of Justice

Wright S, Hazel N, Liddle M, Renshaw J and Gray P (2013) Evaluation of the South West Resettlement Consortium: Final Report London: Ministry of Justice

Youth Justice Board (2014) Pathways to Resettlement. London: Youth Justice Board 